KRISTINA M. RANĐELOVIĆ ${ }^{1}$

UNIVERSITY OF Niš, FACULTY OF PHILOSOPHY

Department of Psychology

JELENA D. ŽELESKOV Đorić

\title{
FEAR OF NEGATIVE EVALUATION AND SOCIAL ANXIETY IN THE CONTEXT OF THE REVISED REINFORCEMENT SENSITIVITY THEORY
}

ABSTRACT. The main goal of this research paper is to examine the predictive power of personality traits in relation to fear of negative evaluation and social anxiety. The revised Reinforcement Sensitivity Theory (rRST) postulates the existence of three major personality systems - Behavioural Inhibition System (BIS), Behavioural Activation System (BAS), and Fight-Flight-Freeze System (FFFS). In order to assess the personality traits, the Reinforcement Sensitivity Questionnaire was used (RSQ). Fear of negative evaluation was assessed using the Fear of Negative Evaluation Scale - Brief form (FNE-B), while social anxiety evaluation was obtained by Social Anxiety Scale (SA2). The sample consisted of 222 psychology students engaged in $1^{\text {st }}$ and $2^{\text {nd }}$ year of studies at the University of Niš and the University of Novi Sad. In order to respond to the research questions, two separate multiple regression analyses were performed. In both analyses, personality traits were the

$1 \quad$ kristina.randjelovic@filfak.ni.ac.rs; jelena.zeleskovdoric@cdu.edu.au

The development of this research paper was partly funded by the Ministry of Science and Technological Development of the Republic of Serbia within the project: Indicators and models of harmonizing family and work roles 179002D.

This paper was submitted on August 5, 2017 and accepted for publication at the meeting of the Editorial Board held on September 19, 2017. 
predictors, while the differences were linked to the criteria variables Model $_{1}$ - fear of negative evaluation, and Model $_{2}$ - social anxiety. Both models were statistically significant. According to the results, Fear of negative evaluation model explains a total of $41 \%$ of the criteria variance, while Social anxiety model explains $46 \%$ of the criteria variance. In both models, BIS stands out as the statistically significant and the best predictor. When comparing the results of both models, the differences relate to the second significant predictor. Namely, Fight response stands out in the first model, while Freeze response stands out in the second one. The obtained findings are discussed and interpreted in the context of rRST.

KEYWORDS: revised Reinforcement Sensitivity Theory, personality traits, fear of negative evaluation, social anxiety.

INTRODUCTION

In the context of personality structure, fear of negative evaluation and social anxiety represent a part of neuroticism, the basic dimension of personality which represents the degree of reactivity to potentially threatening stimuli with frequent feelings of stress (Smederevac, Mitrović, \& Čolović, 2010). Even though both constructs belong to the domain of neuroticism, the fear of negative evaluation is a narrower construct than social anxiety. Social anxiety is a personality disposition and tendency to respond to social stimuli with irritability, unease, and discomfort (Leary, 1996), while the fear of negative evaluation is a core feature of social anxiety as a dimensional personality trait. When compared to other forms of anxiety (e.g. general, preoperative anxiety), social anxiety as a phenomenon is related to the individual's belief that the one is being assessed by others in a social context (Schlenker \& Leary, 1982). According to some authors social anxiety can also be called evaluation anxiety or "fear of judgment", because it implies interpersonal evaluation in a real or imaginary social setting (Watson \& Friend, 1969).

Unlike shyness that is characterized by emotional and behavioural ambivalence (fear and satisfaction; accession and withdrawal), social anxiety includes the discomfort and motivation to avoid situations that contribute to the feeling of social discomfort (Reddy, 2005). According to Leitenberg (1990) the social anxiety includes emotional distress and self-consciousness in situations of anticipation or actual evaluation by others. Moreover, the 
multidimensionality of the social anxiety construct primarily emphasizes the existence of a negative emotional component, as well as the withdrawal and inhibitory behaviour in socially uncomfortable situations (Tovilović, 2004). Buttermore (2009) and Schwarzer (1986) define four components of social anxiety - cognitive, affective, behavioural, and physiological. The first refers to negative self-evaluation or low self-esteem. The second one is linked with negative feelings, primarily stress and discomfort in socially threatening situations. The last two are related to the withdrawal and inhibition in the presence of other people, as well as to the symptoms of the activation of the autonomic nervous system, whose basic task is to defend us from danger. Based on the results obtained by examining the latent structure of the social anxiety scale, Tovilović (2004) reported on the existence of four dimensions of social anxiety which are the dispositional personality traits: social evaluation anxiety, inhibition in socially uncertain situations, low self-esteem, and hypersensitivity to rejection. Social evaluation anxiety implies the experience of anxiety in situations when a person is observed and evaluated. Inhibition in socially uncertain situations indicates the difficulties in social functioning, that is, the inhibition of behaviour under certain social circumstances, as well as the perception of oneself and one's behaviour as shy, especially in situations involving uncertainty, such as new situations and unknown people. Perceiving oneself as an unconfident person, and a person who lacks self-respect and who doubts one's own merit, indicates that it is the low self-esteem dimension. Hypersensitivity to rejection includes the indicators such as the perception of the family as the only safe environment, hypersensitivity due to the fear of judgments, and beliefs that others perceive the person in negative terms. Self-perception determines how individuals will feel and act in situations when exposed to the evaluation by other people, therefore positive self-image and high self-esteem are "protective factors" when experiencing social discomfort. In contrary, negative self-image and the low self-esteem lead to a concern about others and their possibility to discover negative traits in person which can cause the rejection. Therefore, social anxiety is a natural reaction of an individual to socially threatening stimuli. Hence, the basic assumption is that the core characteristic of social anxiety is the concern or fear of negative evaluation (Clark \&Wells, 1995; Rapee \& Heimberg, 1997; Watson \& Friend, 1969). However, there are also other perceptions 
of the social anxiety phenomenon. For example, Weeks, Heimberg, \& Rodebaugh (2008a) assumed and empirically confirmed that fear of evaluation is basically the core of social anxiety. In other words, fear of evaluation generally involves two components - fear of negative evaluation and fear of positive evaluation (Weeks, Heimberg, Rodebaugh, \& Norton, 2008b). Fear of positive evaluation refers to a person's concern that positive evaluation of one's work or personality can raise social standards based on which the individual will be assessed in the future. This concern comes with the doubt that an individual will meet such criteria. As a result, positive evaluation is seen as an aversive stimulus, as well as the anticipation that the expected favourable evaluation will turn into failure (Wallace \& Alden, 1995, 1997).

A theory of personality that is particularly important to explain the phenomenon of social anxiety is the revised Reinforcement Sensitivity Theory (Gray \& McNaughton, 2000). According to Reinforcement Sensitivity Theory (rRST), there are three neurophysiological personality systems responsible for individual differences in learning, motivation, behaviour, and the occurrence of disorders. These systems are: Behavioural Inhibition System BIS; Behavioural Activation System - BAS, and Fight-Flight-Freeze System - FFFS. The difference among these systems refers to the neurophysiological basis, the stimuli that trigger their activation, the behavioural reactions which they lead to, the personality traits they correspond to, and the disorders whose occurrence and persistence these systems contribute to.

BIS is the threat assessment system and behaviour control system, and its primary objective is to resolve conflicts (conflicts within FFFS and BAS, or between the two (FFFS-FFFS, BAS-BAS, FFFS-BAS)). In order to activate BIS, two requirements need to be met: 1) the presence of stimuli that are in a conflicting relationship, and 2) increased alertness (Gray \& McNaughton, 2000; quoted by Smederevac, Mitrović, Čolović, \& Nikolašević, 2014). In other words, stimulus as such is not important; what is important is the meaning attributed to it (McNaughton \& Corr, 2004). Accordingly, BIS is a significant factor in assessing the environment as potentially threatening and is activated in situations where a person experiences a high degree of anxiety due to the detection of potential threat, that is, when the individual is forced to react. At the personality level, BIS corresponds to anxiety. As part of this personality system, threat assessment is done by monitoring internal and 
external environment (increased organism excitement, increased attention threshold, directing attention to certain stimuli, recalling past events that may be helpful in assessing threats). After assessing the threat, BIS controls behaviour by inhibiting it, by increasing caution, etc. When facing threat, and depending on the characteristics of the stimulus, as well as on the assessment of the BIS, defensive modes are activated (Fight-Flight-Freeze). Therefore, BIS actually imply the internal capacity to deal with a threat, i.e. a subjective evaluation of the stimulus. The BIS-related behaviour is the defensive approach to threat, in order to evaluate it. The hypersensitivity of BIS can be the basis of general anxiety disorder and neurotic depression (Pickering \& Corr, 2008).

Behavioural Activation System (BAS) is a system in charge of reactions to access bonus signals and an active avoidance of punishment. BAS is a system in charge of reactions to reward indicators and of active avoidance of punishment. The stimulus that activates the BAS includes all appetitive stimuli (conditional and unconditional) (Pickering \& Corr, 2008). Situations that are considered new and exciting trigger BAS reaction. On the manifestation level, BAS is reflected in active and exploratory behaviour with the goal of reaching the confirmation, while at the level of personality traits, BAS corresponds to impulsivity. Therefore, individuals with a very pronounced BAS sensitivity can be identified by their difficulty to control the impulses, risky and impulsive behaviour, as well as the increased need for excitement (Smederevac, Čolović, \& Mitrović, 2009). BAS is an appetitive brain system whose hypersensitivity is the basis for mania, while the reduced reactivity of BAS is associated with depression coupled with anxiety. In addition to this, addictive behaviours (such as pathological gambling), as well as various types of high-risk and impulsive behaviours can be attributed to the increased activation of the BAS system (Pickering \& Corr, 2008).

Fight-Flight-Freeze System (FFFS) represents the defensive system against the current threat. Unlike the BAS system which is in charge of activating behaviours linked to appetitive stimuli, FFFS is responsible for behaviours that are associated with all the unconditional and conditional aversive stimuli (Pickering \& Corr, 2008). While BIS is responsible for the way people perceive certain situations as threatening, FFFS is in charge of the reactions to aversive, that is, to the feelings related to the unconditional punishment or lack of reward, as well as the signs of reward or lack of reward 
(Smederevac et al., 2014). Possible reactions to the above mentioned stimuli are fight, flight or "freeze", with different emotional states at the basis of these behaviours (fight - anger, flight - fear, freeze - panic). Fight is an explosive and disorganized reaction to an imminent threat (Smile, Pickering, \& Jackson, 2006; quoted by Smederevac et al., 2014), but it should not be confused with predatory or instrumental aggression, which is associated with BAS (Harmon-Jones \& Sigelman, 2001; quoted by Smederevac et al., 2014). Flight is defined as a reaction to an actual threat that can be avoided. Avoidance response occurs when the threat is very close or intense (Gray \& McNaughton, 2000), but still far enough to be avoided. The oversensitivity of the FFFS system is one of the main reasons for panic disorders and specific phobias to occur and persevere (Gray \& McNaughton, 2000; Kimbrel, 2008; Zinbarg \& Lira Yoon, 2008).

Generally speaking, the BAS is linked with the extraversion and tendency to experience positive emotions, while BIS is linked with neuroticism, anxiety, depression, and negative emotions (Gable, Reis, \& Elliot, 2000; Johnson, Turner, \& Iwata, 2003). According to Corr (2002), people who have high BIS and low BAS are more sensitive to punishment and are more likely to experience negative emotions, such as anxiety and fear. Furthermore, BIS and FFFS have a positive correlation with the tendency toward anxiety response, that is, with the personality traits that are characterized by avoidance response (Coles \& Horng, 2006), one of them being social anxiety. Therefore, it can be said that there is an indirect empirical confirmation of a positive link between BIS, or FFFS, and social anxiety, as well as a negative correlation between BAS and social anxiety.

Ly (2011) conducted a series of research where he examined the relevance of the constructs of the revised Reinforcement Sensitivity Theory in order to explain and predict social anxiety. In the first series of research, he confirmed a consistent pattern of positive correlation between BIS and both types of social anxiety (anxiety in social interactions and observational social anxiety). However, FFFS showed a positive correlation with the observational social anxiety, but not with the anxiety in social interactions. This coincides with the findings of some other studies (Krueger, 1999; Krueger, Caspi, Moffitt, \& Silva, 1998), which suggest that fear (FFFS) and anxiety/distress (BIS) show various links with neurotic disorders. Thus fear (FFFS) is primarily associated with social 
phobia (Krueger, 1999; Krueger et al, 1998), while anxiety/distress (BIS) is linked to social anxiety disorder. Kimbrel (2012) did a survey on a sample of American students, regarding the speech in front of an audience and investigated the level of social anxiety before the actual speech in front of an audience. This author assumed and confirmed that in a social threat situation, social anxiety is in a positive correlation with BIS and FFFS. The results supported the moderate correlation between BIS, FFFS, and social anxiety. Furthermore, Kimbrel reported on the low negative correlation between BAS and social anxiety in a situation of social danger anticipation. Apart from this, in some studies, there was a significant negative correlation between BAS and social anxiety (e.g. Coplan et al., 2006; Kashdan, 2002), while in some other studies there was no correlation whatsoever (Kashdan \& Robert, 2006; Kimbrel et al., 2008). Based on available research studies, it can be concluded that BIS is the strongest positive correlate of both modalities of social anxiety, while the activation of FFFS is primarily linked with the situations associated with fear stimuli (e.g. speech in front of an audience). Although the role of the BAS is mainly related to social anxiety in interactions, it can be said that the increased reactivity of BAS is a protective factor when experiencing social discomfort (Kimbrel, 2012).

Considering the relevance of the revised Reinforcement Sensitivity Theory to explain the social anxiety phenomenon, as well as the lack of research on this subject in Serbia, the main goal of this research is to examine the relationship between the personality traits postulated by rRST and the fear of negative evaluation, as well as social anxiety as dispositional personality trait.

\section{METHOD}

SAMPLE AND

PROCEDURE
The initial sample of respondents consisted of 237 psychology students from two universities in Serbia - the University of Niš and the University of Novi Sad. Majority of students were from the University of Niš (67.6\%) and one-third of participants were from the University of Novi Sad (32,4\%). The sample comprised of $54.1 \%$ of the $1^{\text {st }}$ year psychology students and $45.9 \%$ of those who were the $2^{\text {nd }}$ year in psychology. There were no multivariate outliers in the sample $\left(?^{2}{ }_{(18)}>42.31, \mathrm{p}<.001\right.$, Tabachnick \& Fidell, 2007), while 15 univariate outliers $(\mathrm{z}>+/-2.50)$ were discarded, with the final 
sample included 222 respondents. There were 30 male and 192 female participants in the study, aged between 18 and $29(\mathrm{M}=19.93$; $\mathrm{SD}=1.08)$.

The survey was conducted anonymously and voluntarily in cities of Niš and Novi Sad.

INSTRUMENTS Reinforcement Sensitivity Questionnaire (RSQ) (Serbian - UOP; Smederevac, Mitrović, Čolović, \& Nikolašević, 2014) consists of 29 items with the four-level answering format (1 - strongly disagree; 4 strongly agree). The questionnaire included the dimensions of the revised Reinforcement Sensitivity Theory: BIS (7 items; e.g. "I find it hard to make decisions because I'm never sure what's the right choice"), BAS (6 items; e.g. "I take on a challenge with enthusiasm") and Fight (6 items; e.g. "As soon as someone hurts me I respond immediately"), Flight (5 items; e.g. "When I'm in a dangerous situation, I look for all possible ways to escape") and Freeze (5 items; e.g. "When someone yells at me I freeze"). In a research conducted by Smederevac et al. (2014) the reliability of subscales ranges from $?=.69$ for Flight, to $?=.87$ for Freeze (BIS $?=.86$; $\mathrm{BAS} ?=.78$ and Fight $?=.82$ ).

Fear of Negative Evaluation Scale - Brief form (FNE-B; Leary, 1983) was used to evaluate fear of negative evaluation, which is at the core of social anxiety as a dispositional characteristic. It consisted of 12 items and the respondents were provided with the five-level answering format $(1-$ not at all characteristic or true of me; 5 - extremely characteristic or true of $m e$ ) in order to assess the degree each characteristics applies to the individual (e.g. I worry too much about what other people will think of me; I am frequently afraid of other people noticing my shortcomings; I am afraid others will not approve of me). Scores range from 12 to 60 , while 4 items are scored in reverse. The scale showed good internal consistency on a sample of Serbian nationality adolescents (?=.87) (Mladenović \& Knebl, 1999).

Social Anxiety scale (SA2; Tovilović, 2004) is used to evaluate social anxiety as a dispositional characteristic. The scale consisted of the five-level answering format (1 - completely false; 5 - completely true) while the theoretical range of scores goes from 25 to 125 . High scores on the scale are an indicator of a more pronounced social anxiety. Examples of some of the items are:" When I am talking to someone, I worry about what they may be thinking about me"; "I find it difficult to establish contact with unknown people"; "I often lack self-confidence"; "I'm afraid that other people will reject me". 
In some other surveys the scale showed high measurement reliability $(?=.96)$ even on the non-clinical sample of respondents (Alinčić, 2013).

DATA The first step during the data preparation phase was to clear the PRoCESSING data matrix from the missing values using the Expectation Maximization Method, that is, EM algorithm (Tabachnik \& Fidell, 2007). In the next step, the correlation analysis and the multiple regression analysis were used to examine the relationships between personality traits and fear of negative evaluation, as well as social anxiety. Personality traits were treated as predictive variables, while fear of negative evaluation and social anxiety represented criteria.

\section{RESULTS}

\section{DESCRIPTIVE INDICATORS}

Distributions of scores obtained through the evaluation of personality traits, fear of negative evaluation and social anxiety do not deviate from normal distribution, as indicated by the coefficients of asymmetry and tailedness (Table 1). Score deviation from the normal distribution was not to be expected, since the sample used was non-clinical. Measurement reliability of the used scales and questionnaires is satisfactory, with the exception of the subscale for Flight evaluation. Cronbach's alpha coefficient was the highest for the social anxiety scale, while the second highest coefficient was for the fear of negative evaluation scale. Subscales for the evaluation of personality traits show the lowest internal consistency. 


\begin{tabular}{lllllllll}
\hline \multicolumn{1}{c}{ VARIABLES } & & MIN & MAX & M & SD & SK & KU & A \\
\hline Personality traits & BIS & 1.00 & 3.57 & 2.24 & .55 & .084 & -.469 & .77 \\
& BAS & 1.67 & 4.00 & 2.84 & .50 & -.071 & -.648 & .72 \\
& Fight & 1.00 & 3.67 & 2.41 & .58 & .046 & -.398 & .78 \\
& Flight & 1.40 & 3.80 & 2.60 & .49 & -.081 & -.448 & .50 \\
& Freeze & 1.00 & 3.20 & 1.88 & .56 & .132 & -.897 & .72 \\
\hline Fear of negative evaluation & FNE & 1.00 & 3.75 & 2.59 & .61 & -.077 & -.685 & .83 \\
\hline Social anxiety & SA & 1.20 & 3.88 & 2.41 & .60 & .257 & -.699 & .90 \\
\hline \hline
\end{tabular}

TABLE 1: DESCRIPTIVE INDICATORS OF VALUES OBTAINED THROUGH THE EVALUATION OF PERSONALITY TRAITS, FEAR OF NEGATIVE EVALUATION AND SOCIAL ANXIETy $(\mathrm{N}=222)$ [TABELA 1.

DESKRIPTIVNI POKAZATELJI MERA DOBIJENIH PROCENOM OSOBINA LIČNOSTI, STRAHA OD NEGATIVNE EVALUACIJE I SOCIJALNE ANKSIOZNOSTI $(\mathrm{N}=222)]$

Note. Mean (M); Standard Deviation (SD); asymmetry coefficient -Skewness (Sk); tailedness coefficient - Kurtosis (Ku); Cronbach's alpha coefficient ( $\alpha$ ); FNE - fear of negative evaluation; $S A$ - social anxiety.

\section{INTER-CORRELATION BETWEEN RESEARCH VARIABLES}

Based on the results obtained by using the Pearson correlation coefficient (Table 2), it can be concluded that the inter-correlation coefficients between personality traits, fear of negative evaluation and social anxiety range from the low of -.18 to the medium of .65 . The strongest positive correlation existed between BIS on one hand, and fear of negative evaluation and social anxiety on the other hand; as well as between the fear of negative evaluation and social anxiety. More specifically, people who have an increased reactivity of BIS are more likely to care about the impression they make on other people, that is, they have a tendency to respond with social discomfort to "socially threatening" stimuli. This was in line with the expectations, since all three constructs basically have a tendency towards an anxiety response. In other words, the abovementioned variables are conceptually similar, because they cover the reactions to socially aversive stimuli. 


\begin{tabular}{crrrrrl}
\hline & \multicolumn{1}{l}{ BIS } & \multicolumn{1}{l}{ BAS } & FIGHT & \multicolumn{1}{l}{ FLIGHT } & FREEZE & FNE \\
\hline BIS & & & & & & \\
BAS & $-.45^{* * *}$ & & & & & \\
FIGHT & .07 & .12 & & & & \\
FLIGHT & $.34^{* * *}$ & $-.18^{* *}$ & .004 & & & \\
FREEZE & $.54^{* * *}$ & $-.26^{* * *}$ & -.08 & $.40^{* * *}$ & & \\
FNE & $.63^{* * *}$ & $-.29^{* * *}$ & -.06 & $.23^{* * *}$ & $.36^{* * *}$ & \\
SA & $.65^{* * *}$ & $-.35^{* * *}$ & -.05 & $.29^{* * *}$ & $.51^{* * *}$ & $.65^{* * *}$ \\
\hline \hline
\end{tabular}

TABLE 2: INTER-CORRELATION BETWEEN RESEARCH VARIABLES $(\mathrm{N}=222)$ [TABELA 2. INTERKORELACIJE VARIJABLI ISTRAŽIVANJA $(\mathrm{N}=222)]$

$$
\text { Note: }{ }^{* *} p<.001 ; * * p<.01 .
$$

When it comes to the correlation between personality traits, it can be noted that the coefficients range from the low of -.18 to the medium of .54, which indicates the absence of multicollinearity, and justifies the inclusion of all personality traits in the prediction model. If the correlation results for personality traits from this study are compared with the results of the RSQ validation study (Smederevac et al., 2014), which was done on a sample of 565 respondents from the general population on the territory of the Republic of Serbia ( $57.5 \%$ were female), it can be said that there are certain similarities, but also some differences between these two. The biggest deviations are related to the correlation between Fight and the remaining personality traits defined by Gray's Model of Personality. Namely, no significant correlation between Fight and other personality traits was observed in this research, while the research by Smederevac et al. (2014) noticed a moderate and positive correlation between Fight and BAS $(\mathrm{r}=.43 ; \mathrm{p}<.01)$, and negative correlation between BAS and Flight, that is, Freeze $(r=-22 ; p<.01 ; r=-27 ; p<.01)$ which is in line with the assumptions that stem from the rRST-a. Smederevac et al. (2014) explained the positive correlation between BAS and Fight in two different ways. First, approaching behaviour is the basis of both personality systems. The difference is that BAS activates the approaching behaviour when appetitive stimuli occur, while Fight activates the approaching behaviour when aversive stimulus happens. Second, a lack of control, impulsive and aggressive behaviour is 
common for both these systems. However, caution is needed when interpreting the link between aggressive behaviour and BAS, or Flight. Namely, BAS is associated with instrumental, predatory or proactive aggression, while Fight is associated with affective, hostile or defensive aggression.

\section{CORRELATION BETWEEN PERSONALITY TRAITS, FEAR OF NEGATIVE EVALUATION AND SOCIAL ANXIETY}

In order to examine the correlation between the personality traits, the fear of negative evaluation, and the social anxiety, two separate multiple regression analyses were conducted. In the first analysis, the criterion variable was the fear of negative evaluation, while in the second analysis the social anxiety was used. The results are shown in Tables 3 and 4.

\begin{tabular}{|c|c|c|c|}
\hline MODEL & PREDICTORS & MODEL SUMMARY & INDEPENDENT CONTRIBUTIONS OF PREDICTORS \\
\hline \multirow[t]{5}{*}{1} & BIS & \multirow{5}{*}{$\begin{array}{l}\mathrm{R}=.64 ; \mathrm{R} 2=.41 ; \Delta \mathrm{R} 2=.39 \\
\mathrm{~F}(5,221)=29.746 ; \mathrm{p}<.001\end{array}$} & $\beta=.635 ; p<.001$ \\
\hline & BAS & & $ß=.014 ; p=.810$ \\
\hline & Fight & & $ß=-.106 ; p=.050$ \\
\hline & Flight & & $ß=.017 ; p=.763$ \\
\hline & Freeze & & $ß=.005 ; p=.936$ \\
\hline
\end{tabular}

TABLE 3: PREDICTION OF SOCIAL ANXIETY BASED ON PERSONALITY TRAITS (ENTER METHOD) $(\mathrm{N}=222)$ [TABELA 3. PREDIKCIJA SOCIJALNE ANKSIOZNOSTI NA OSNOVU OSOBINA LIČNOSTI (ENTER METOD) $(\mathrm{N}=222)]$

Note. $\mathrm{R}$ - Multiple correlation coefficient; $\mathrm{R}^{2}$ - Multiple Coefficient of Determination; $\Delta \mathrm{R}^{2}$ - Adjusted coefficient of determination; $\beta$ Standardized regression coefficient.

The results confirmed that the predictive model is statistically significant (Table 3 ). The set of predictors explains $41 \%$ of the criteria variance (fear of negative evaluation). BIS and Fight stand out as significant predictors (at the very edge of statistical significance). BIS is the best predictor of the fear of negative evaluation, while the direction of the Beta coefficient indicates that with the increase in BIS sensitivity, the concern of making a bad impression on other people increases as well. Furthermore, people who are prone to explosive and disorganized reactions to imminent danger, as well as to 
hostile and aggressive behaviour have a reduced fear of negative evaluation.

\begin{tabular}{|c|c|c|c|}
\hline MODEL & PREDICTORS & MODEL SUMMARY & INDEPENDENT CONTRIBUTIONS OF PREDICTORS \\
\hline \multirow[t]{5}{*}{1} & BIS & $R=.68 ; R 2=.46 ; \Delta R 2=.45$ & $ß=.504 ; p<.001$ \\
\hline & BAS & $F(5,221)=36.744 ; p<.001$ & $ß=-.061 ; p=.281$ \\
\hline & Fight & & $ß=-.060 ; p=.243$ \\
\hline & Flight & & $ß=.026 ; p=.634$ \\
\hline & Freeze & & $ß=.204 ; p<.001$ \\
\hline
\end{tabular}

TABle 4: PREDICTION OF SOCIAL ANXIETY BASED ON PERSONALITY TRAITS (ENTER METHOD) $(\mathrm{N}=222$ ) [TABELA 4. PREDIKCIJA SOCIJALNE ANKSIOZNOSTI NA OSNOVU OSOBINA LIČNOSTI (ENTER METOD) $(\mathrm{N}=222)]$

Note. $R$ - Multiple correlation coefficient; $R^{2}$ - Multiple Coefficient of Determination; $\Delta \mathrm{R}^{2}$ - Adjusted coefficient of determination; $\beta$ Standardized regression coefficient.

Based on the results from the second regression analysis, it can be concluded that the prediction model is statistically significant and it explains $46 \%$ of the criteria variance (Table 4 ). The data show that BIS is consistently the best predictor and a positive correlate of social anxiety. Compared to the results of the previous regression analysis, it can be concluded that in addition to BIS, another important predictor is Freeze, and not Fight. Namely, the Beta coefficient of Freeze indicates that with the increase of Freeze reaction there is a growing tendency towards social anxiety response.

\section{DISCUSSION AND CONCLUSION}

The main goal of this paper was to investigate whether the personality traits from Gray's Model of Personality can contribute to the prediction of social anxiety phenomenon, or more precisely, of the fear of negative evaluation and social anxiety. The reference framework of this research is the revised Reinforcement Sensitivity Theory (rRST) due to the relevance of the theory itself for the explanation, understanding, and prediction of social discomfort as a dispositional trait. Gray and McNaughton (2000) were the first authors who emphasized the importance of rRST for explaining social anxiety. Based on their perceptions, Kimbrel postulated the 
model of social anxiety (Kimbrel, 2008), with the assumption that people with highly active BIS and FFF have a greater tendency to social anxiety, while the BAS was seen as a moderator. More precisely, the level of BAS sensitivity is perceived to be important in determining the impact of the BIS and FFF on behaviour in socially threatening situations, such as, for example, public appearance. If a person has highly active BIS and FFF, and low BAS sensitivity, then BAS is a facilitating factor in case of an "enhanced" social anxiety response to the environment, and vice versa.

Considering previous research and results obtained (e.g. Kimbrel, 2012; Ly, 2011), it was expected that BIS and FFF could be positive correlates of the fear of negative evaluation and social anxiety and that BAS could have a negative correlation with these. Despite the expectation, the results of the present study only partially confirmed the initial assumptions. Namely, in both regression analyses BIS was seen as the strongest and most positive predictor of fear of negative evaluation and social anxiety. This finding is consistent with the expectations derived from rRST, as well as with the models of social anxiety that explain the role of social anxiety as a personality trait.

In the context of rRST, the BIS is seen as a defensive approach system, which is in charge of detecting and resolving conflicts. This role of BIS is accomplished by behavioural inhibition, improved attention, emotional excitement, and active engagement in the evaluation of the external environment (e.g. evaluation of the feedback received by others), as well as using the evaluation of one's inner reality (e.g. recalling one's own behaviour when exposed to judgments by others). However, since BIS has a tendency to process and experience potentially threatening information, avoidance behaviour is favoured here. In other words, the fact that a positive correlation between BIS and the fear of negative evaluation and social anxiety was found is not surprising, since the basic feature of BIS is the tendency to experience tension, restlessness, worry, and discomfort, as well as avoidance behaviour, which at the same time represent the basic affective and behavioural component of the social anxiety phenomenon. This is also confirmed in other research studies (e.g. Hook \& Valentiner, 2002; Kimbrel, 2008, 2012; Lundh \& Ost, 1997; Ly, 2011).

According to the "High-Risk Model" (Buttermore, 2009), social anxiety is an adaptive response to a range of situations characterized by high social risk and the possibility of negative evaluation. 
Therefore, social anxiety is a reaction to a wider range of situations and has two basic purposes: 1) to identify social interactions which could lead to negative evaluation, and 2) to take steps in order to minimize the risk for such experiences to occur (Buttermore, 2009). Subjective evaluation of situational characteristics determines what the social anxiety response will be. Since BIS is the system that evaluates the threats and resolves conflicts, then it can be said that the fear of negative evaluation, as well as social anxiety, are BIS components. None of the models found any significant role of BAS for the prediction of the abovementioned constructs. This is in line with one part of the former empirical record (e.g. Kashdan \& Robert, 2006; Kimbrel et al., 2008). On the other hand, even though a significant link between the BAS and the fear of negative evaluation and social anxiety was not found in the this study, we cannot assume that BAS is not important in explaining and predicting the measures of social anxiety. In contrary to our results, previous studies confirmed a negative correlation between BAS and social anxiety (Coplan et al., 2006; Kashdan, 2002). A possible explanation of obtained results and the main limitation of this study is the sample used in this research. As mentioned, the sample consisted of psychology students, mainly females. This means that the study population was highly selected. In other words, due to certain differences between our respondents and the general population, the variance of individual differences was reduced which could be the reason for the absence of a significant link between BAS and social anxiety. However, this explanation should be taken with a pinch of salt, and the findings obtained should be checked in one of the following surveys, which should include a larger and more representative survey sample. Moreover, some of the former survey results (Kashdan, 2002; Kimbrel, Mitchell, \& Nelson-Gray, 2010) indicate an important role of BAS for the prediction of social anxiety in interactions, but not observational social anxiety (e.g. Kimbrel et al., 2008). Therefore, the recommendation for future studies is to examine both modalities of social anxiety. As a reminder, in this study social anxiety was examined as a general tendency towards negative emotional response and avoidance in socially threatening situations. The findings related to the important predictors of the defensive system against the current threat (FFFS) are very interesting. When it comes to the prediction of fear of negative evaluation, Fight turned out to be a significant (negative) predictor, while Freeze reaction was a significant and positive 
predictor for social anxiety. The tendency to expand the range of situations perceived as potentially threatening is an indicator of the increased level of Fight, which entails frequent aggressive behaviour towards others, because their reactions are interpreted as a threat to personal space.

A possible explanation of the negative link between Fight and the fear of negative evaluation is that the individuals of high Fight response use their aggressive behaviour to protect themselves from a threat to their self-esteem in a social setting.

Freeze response is usually seen as a cognitive phenomenon that manifests itself when there is the inability to articulate a verbal response in a certain threatening situation (Smederevac et al., 2014). However, Freeze response is also defined through the behavioural and affective components which are characteristic of panic. The obtained positive link between Freeze and social anxiety indicates the presence of the fear component when facing social anxiety. In other words, this finding supports the idea that social anxiety, in addition to anxiety, includes fear as well (Gray \& McNaughton, 2000).

In general, the results of this study indicate the importance of personality traits for the prediction of social anxiety. However, as anxiety always appears in a particular social context, the study of situational determinants is an important methodological issue which should be explored in addition to the examination of individual factors. Moreover, in addition to the application of correlational research designs, the experimental ones should also be included in order to test the assumptions arising from rRST more adequately, as well as some of the models of social anxiety. It would also be important to perform studies using the clinical samples, in addition to the general population samples; primarily of the individuals suffering from social anxiety disorder and social phobia. Therefore, the guidelines for future research are more comprehensive observation and examination of the social anxiety phenomenon.

REFERENCES

Alinčić, M. (2013). Osobine ličnosti i asertivnost kao prediktori samopoštovanja i socijalne anksioznosti. Primenjena psihologija, 6(2), 139-154.

Buttemore, R. N. (2009). The evolved function of social anxiety: Detecting high stakes social interactions. Dissertation theses. Michigan: University of Michigan. 
Clark, D. M., \& Wells, A. (1995). A cognitive model of social phobia. In: R. G. Heimberg, M. R. Liebowitz, D. A. Hope, \& F. R. Schneier (Eds.), Social phobia: Diagnosis, assessment and treatment (pp.69-93). New York: Guilford Press.

Coles, M. E., \& Horng, B. (2006). Social anxiety disorder. In: M. Hersen, J. C. Thomas, \& F. Andrasik (Eds.), Comprehensive handbook of personality and psychopathology: Adult psychopathology, Vol. 2 (pp. 138-153). Hobokn, NJ: John Wiley \& Sons.

Coplan, R. J., Wilson, J., Frohlick, S. L., \& Zelenski, J. (2006). A person-oriented analysis of behavioural inhibition and behavioural activation in children. Personality and Individual Differences, 41(5), 917-927.

Corr, P. J. (2002). J. A. Gray's reinforcement sensitivity theory: Tests of the joint subsystems hypothesis of anxiety and impulsivity. Personality and Individual Differences, 33, 511-532.

Gable, S. L., Reis, H. T., \& Elliot, A. J. (2000). Behavioural activation and inhibition in everyday life. Journal of Personality and Social Psychology, 78, 1135-1149.

Gray, J. A., \& McNaughton, N. (2000). The neuropsychology of anxiety: An enquiry into the functions of the septo-hippocampal system (2nd ed.). New York: Oxford University Press.

Hook, J. N., \& Valentiner, D. P. (2002). Are specific and generalized social phobias qualitatively distinct? Clinical Psychology: Science and Practice, 9, 379-395.

Johnson, S. L., Turner, R. J., \& Iwata, N. (2003). BIS/BAS levels and psychiatric disorder: An epidemiological study. Journal of Psychopathology and Behavioral Assessment, 25, 25-36.

Kashdan, T. B. (2002). Social anxiety dimensions, neuroticism, and the contours of positive psychological functioning. Cognitive Therapy and Research, 26, 789-810.

Kashdan, T. B., \& Roberts, J. E. (2006). Affective outcomes in superficial and intimate interactions: Roles of social anxiety and curiosity. Journal of Research in Personality, 40(2), 140-167.

Kimbrel, N. A. (2008). A model of the development and maintenance of generalized social phobia. Clinical Psychology Review, 28, 592-612.

Kimbrel, N. A. (2012). BIS, BAS and Bias: The role of personality and cognitive bias in social anxiety. Personality and Individual Differences, 52, 395-400.

Kimbrel, N. A., Cobb, A. R., Mitchell, J. T., Hundt, N. E., \& Nelson-Gray, R. O. (2008). Sensitivity to punishment and low maternal care account for the link between bulimic and social anxiety symptomatology. Eating Behaviors, 9, 210 217. 
Kimbrel, N. A., Mitchell, J. T., \& Nelson-Gray, R. O. (2010). An examination of the relationship between behavioral approach system (BAS) sensitivity and social interaction anxiety. Journal of Anxiety Disorders, 24, 372-378.

Krueger, R. F. (1999). The structure of common mental disorders. Archives of General Psychiatry, 56, 921-926.

Krueger, R. F., Caspi, A., Moffitt, T. E., \& Silva, P. A. (1998). The structure and stability of common mental disorders (DSM-III-R): A longitudinal-epidemiological study. Journal of Abnormal Psychology, 107, 216-227.

Leary, M. R. (1983). A brief version of the Fear of Negative Evaluation Scale. Personality and Social Psychology Bulletin, 9, 371-376.

Leary, M. R. (1996). Self-presentation: Impression management and interpersonal behavior. Oxford: Westview press.

Leitenberg, H. (1990). Handbook of social and evaluation anxiety. New York: Plenum.

Lundh, L. G., \& Ost, L. G. (1997). Explicit and implicit memory bias in social phobia. The role of subdiagnostic type. Behaviour Research and Therapy, 35(4), 305-317.

Ly, C. (2011). The relevance of reinforcement sensitivity theory to social anxiety and response to cognitive behavioural therapy for social anxiety disorder. Dissertation theses. University of Tasmania.

McNaughton, N., \& Corr, P. J. (2004). A two-dimensional neuropsychology of defense: Fear/anxiety and defensive distance. Neuroscience and Biobehavioral Reviews, 28, 285-305.

Mladenović, U., \& Knebl, J. (1999). Religioznost, aspekti self-koncepta i anksioznost adolescenata. Psihologija, (1-2), 83-96.

Pickering, A. \& Corr, P. (2008). J. A. Gray's Reinforcement Sensitivity Theory (RST) of Personality. In: G. J. Boyle, G. Matthews \& D. H. Saklofske (Eds.), The SAGE Handbook of Personality Theory and Assessment - Vol 2 Personality Measurement and Assessment (pp. 239-256). Los Angeles: Sage.

Rapee, R. M., \& Heimberg, R. G. (1997). A cognitive behavioral model of anxiety in social phobia. Behavior Therapy and Research, 35, 741-756.

Reddy, V. (2005). Feeling shy and showing-off: Self-conscious emotions must regulate self-awareness. In: N. Jacqueline \& M. Darwin (Eds.), Emotional development: Recent research advances (pp. 183-204). Oxford, England: Oxford University Press.

Schlenker, B. R., \& Leary, M. R. (1982). Social anxiety and self-presentation: A conceptualization and model. Psychological Bulletin, 92, 641-669.

Smederevac, S., Mitrović, D. i Čolović, P. (2010). Velikih Pet plus Dva. Beograd: Centar za primenjenu psihologiju. 
Smederevac, S., Mitrović, D., Čolović, P. i Nikolašević, Ž. (2014). Validation of the measure of revised reinforcement sensitivity. Journal of Individual Differences, 35(1), 12-21.

Smederevac, S., Čolović, P. i Mitrović, D. (2009). Procena osetljivosti na potkrepljenje. U Biro, M., Smederevac, S. i Novović, Z. (ured.), Procena psiholoških i pishopatoloških fenomena (str. 89-100). Beograd: Centar za primenjenu psihologiju.

Tabachnick, B. G., \& Fidell, L. S. (2007). Using Multivariate Statistics (6th edition). Boston: Pearson/Allyn \& Bacon.

Tovilović, S. (2004). Latentna struktura Skale socijalne anksioznosti i relacije između socijalne anksioznosti i iracionalnih uverenja. Psihologija, 37(1), 6388.

Wallace, S. T., \& Alden, L. E. (1997). Social phobia and positive social events: The price of success. Journal of Abnormal Psychology, 106, 416-424.

Watson, D., \& Friend, R. (1969). Measurement of social-evaluative anxiety. Journal of Consulting and Clinical Psychology, 33, 448-457.

Zinbarg, R. E., \& Lira Yoon, K. (2008). RST and clinical disorders: Anxiety and depression. In: P. J. Corr (Ed.), The Reinforcement Sensitivity Theory of personality (pp. 360-397). Cambridge University Press.

КРИСТИНА М. РАНЪЕЛОВИЋ

УНИВЕРЗИТЕТ У НИШУ

ФИЛОЗОФСКИ ФАКУЛТЕТ

ЈЕЛЕНА Д. ЖЕЛЕСКОВ ЂОРИЋ

УНИВЕРЗИТЕТ ЧАРЛС ДАРВИН

АУстРАЛИЈА

РЕЗИМЕ

СТРАХ ОД НЕГАТИВНЕ ЕВАЛУАЦИЈЕ И СОЦИЈАЛНА АНКСИОЗНОСТ У КОНТЕКСТУ РЕФОРМУЛИСАНЕ ТЕОРИЈЕ ОСЕТЉИВОСТИ НА ПОТКРЕПЉЕЬЕ

Референтни оквир истраживања је реформулисана теорија осетљивости на поткрепљење (rRST), односно Грејов модел личности који постулира постојање три ठазична система личности: 1) систем ठихејвиоралне инхибиције - BIS; 2) систем бихејвио-

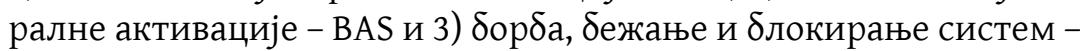
FFFS. BIS представља систем процене претње и систем контроле понашања, а његов основни циљ јесте решавање конфликата (конфликти унутар FFFS-a, BAS-а или између оба (FFFS-FFFS, BAS-BAS, FFFS-BAS)). BAS је систем задужен за реакције присту- 
пања на сигнале награде и активно избегавање казне. Стимулуси који активирају BAS обухватају све апетитивне стимулусе (условне и безусловне). FFFS представља систем одбране од актуелне опасности и одговоран је за понашања која се доводе у везу са свим аверзивним стимулусима (безусловним и условним). Према rRST-y, BIS и FFFS су позитивни корелати индикатора социјалне анксиозности, док је BAS у негативној релацији са друштвеном нелагодношћу. Имајући у виду релевантност rRST-a за објашњење социјално анксиозност феномена, као и недостатак истраживања на ту тему, основни циљ овог истраживања је испитивање релација између особина личности постулираних рРСТ-ом и страха од негативне евалуације, као и социјалне анксиозности као диспозиционог обележја личности.

Узорак испитаника чинило је 222 студената I и II године са Департмана за психологију Филозофског факултета у Нишу, као и са Одсека за психологију Филозофског факултета у Новом Саду. Од тога је било 192 девојке (86.5\%), док се старост испитаника кретала од 18 до 29 година (M = 19.93; SD =1.08). У циљу процене особина личности коришћен је Упитник осетљивости на поткрепљење (УОП). Страх од негативне евалуације процењиван је применом Скале страха од негативне евалуације - краћа форма (FNE - B), док је социјална анксиозност операционализована преко скорова добијених на Скали социјалне анксиозности (СА2). Како $\delta$ и се дошло до одговора на постављена истраживачка питања, коришћене су две одвојене вишеструке регресионе анализе. У обе анализе предиктори су биле особине личности, док се разлика тицала критеријумских варијабли (Модел 1 - страх од негативне евалуације и Модел 2 - социјална анксиозност). оба модела су статистички значајна (Модел 1 : $\mathrm{F}_{(5,221)}=29.746 ; \mathrm{p}<.001$; Модел $_{2}: \mathrm{F}_{(5,221)}=36.744 ;$ p<.001). Модел 1 објашњава укупно $41 \%$ варијансе критеријума, док Модел 2 објашњава $46 \%$ варијансе критеријума. BIS се у оба модела издваја као статистички значајан и најбољи предиктор (Модел 1 : $=.635 ;$ р<.001; Model $_{2}$ : $=.504$; p<.001). Када се пореде резултати оба модела разлика се тиче другог значајног предиктора. Наиме, у првом моделу се издваја Борба $(\beta=-.106 ; p=.050)$, а у другом Блокирање $(\Omega=.204 ; p<.001)$.

Генерално, резултати овог истраживања указују на важност особина личности у предикцији мера социјалне анксиозности. Добијени налази су у складу са очекивањима и интерпретирани су у контексту rRST-a, као и претходних емпиријских података. Како се социјална анксиозност увек испољава у одређеном дру- 
штвеном контексту, проучавање ситуационих детерминанти представља важно методолошко питање, те је погодно да истраживања овог феномена поред испитивања индивидуалних чинилаца укључују и ту групу предиспонирајућих фактора. Смернице за наредна истраживања иду у правцу обухватнијег сагледавања и испитивања феномена социјалне анксиозности.

КљУчнЕ РЕчи: реформулисана теорија осетљивости на поткрепљење, особине личности, страх од негативне евалуације, социјална анксиозност.

Овај чланак је објављен и дистрибуира се под лиценцом Creative Commons Ауторство-Некомерцијално Међународна 4.0 (СС BY-NC 4.0 |

https://creativecommons.org/licenses/by-nc/4.0/).

This paper is published and distributed under the terms and conditions of the Creative Commons Attribution-NonCommercial International 4.0 licence (CC BY-NC 4.0 | https://creativecommons.org/licenses/by-nc/4.0/). 